\title{
Effect of collagen and collagen peptides from bluefin tuna abdominal skin on cancer cells
}

\author{
Sung-Hee Han*, Yuki Uzawa, Tatsuya Moriyama, Yukio Kawamura
}

Department of Applied Biological Chemistry, Graduate School of Agriculture, Kinki University, Naka-Machi, Nara, Japan; *Corresponding Author: ykawamur@nara.kindai.ac.jp

Received 27 December 2010; revised 17 February 17 2011; accepted 28 February 2011.

\begin{abstract}
In the present study, we investigated the effect of collagen and collagen peptides from bluefin tuna abdominal skin on cancer cells. Collagens were extracted from bluefin tuna (Thunnus orientails) abdominal, mackerel, and carp skin. The calf and salmon collagen were used reagent grade as a standard samples. The main protein band pattern produced by SDS-PAGE of all collagen samples consisted of two chains and one chain. For collagen peptides samples, bluefin tuna abdominal skin collagen and salmon skin collagen were hydrolyzed by trypsin. Among samples, salmon, mackerel, carp collagen, and their collagen peptides did not significantly reduce relative cell growth. However, the bluefin tuna abdominal skin collagen dramatically reduced HepG2 and HeLa cell growth by over $50 \%$ relative in a concentration-dependent manner when added to cells seeded 96-well plates. This suggests the collagen adding time was mightily important for effect of the collagen.
\end{abstract}

Keywords: Bluefin Tuna Skin Collagen; Type I Collagen; HepG2 Cell; HeLa Cell

\section{INTRODUCTION}

To date, many researchers have reported the prevention of cancer both in vitro and in vivo by administration of various functional foods or their extraction components [1]. Collagen is a common protein and significant part of the living bodies of mammals. As a structural protein, collagen is essential to creating physical structure, and as an extracellular matrix protein, it acts as a supporting framework over which cells are arranged [2]. Collagen has been utilized as a material in foods, cosmetics, pharmaceuticals, and experimental reagents. Commercial sources of collagen usually include mam- mals such as cows or pigs; however, marine animals have garnered increased attention as a backup collagen resource ever since the onset of bovine spongiform encephalopathy (BSE) in the cattle industry [3].

These days, consumption of fish worldwide has increased, especially with the Japanese, who consume a wide range of fish species [4]. Particularly, bluefin tuna (Thunnus Orientails) is one of the most popular types of tuna in Japan, and its consumption is always increasing. However, such large demand has resulted in large quantities of fish wastes, including skin, bone, and fins, produced by many fish shops and fish-processing factories. These wastes are usually dumped, resulting in pollution and an offensive odor [5]. Therefore, recent studies have focused on the extraction of collagen and from fish wastes. Studies have reported the effect of animal collagen on osteoporosis [6]. For example, there have been numerous studies supporting the hypothesis that collagen from shark contains antiangiogenic and antitumor compounds [7]. However, collagen from bluefin tuna as a functional component as well as its effect on cancer cells has not been studied.

In this study, we report the preparation of type I collagen and collagen peptides from bluefin tuna as well as their actions on HepG2 (Human hepatocellular liver carcinoma cell line) and HeLa cells (Human cervical cell line).

\section{MATERIALS AND METHODS}

\subsection{Collagen Preparations}

Bluefin tuna (Thunnus orientails) was obtained in an unfrozen state at $4^{\circ} \mathrm{C}$ within $24 \mathrm{hr}$ after catching from the tuna cultivation fields of Kinki University, Japan. The skin of bluefin tuna was dissected from the body and stored at $-20^{\circ} \mathrm{C}$. Bluefin tuna abdominal skin type I collagen and other collagens were isolated according to previously reported procedures $[1,8]$ with slight modifi- 
cation. The collagen extraction methods can be divided into three steps as follows: Defatting, acid extraction with protease, and salting out and dialysis. Our method is based on previous research on the extraction of type I collagen. The final protein recovery rate of type I bluefin tuna abdominal skin collagen was $1.8 \mathrm{~g} / 100 \mathrm{~g}$ and the dry yield was $4.1 \%$. This yield was similar to those of previous reports featuring acetic acid soluble extraction. Briefly, the abdominal skin of bluefin tuna without muscle and scales was washed under running water and cut into small pieces. The pieces were then defatted three times with $\mathrm{MeOH} / \mathrm{CHCl}_{3}$ (2:3) and then washed by methanol and water. Second step was Extraction in acid solution was carried out next at $4^{\circ} \mathrm{C}$. The defatted pieces were homogenized in $10 \mathrm{vol}(\mathrm{w} / \mathrm{v})$ of $0.5 \mathrm{M}$ acetic acid for $5 \mathrm{~min}$ at 10,000 rpm using a homogenizer (AM-1, NIHONSEIKI KAISHA Ltd., Japan). The homogenates were kept at $4^{\circ} \mathrm{C}$ for 24 hrs with continuous stirring. The suspension was centrifuged $(10,000 \times \mathrm{g}, 30 \mathrm{~min})$ to remove any residue. Pepsin (3130 U/mg solid; Nacalai tesque INC. Kyoto, Japan) was then added to the supernatant (7 $\mu \mathrm{g} / \mathrm{L})$, and the mixture was gently stirred for 2 days. Collagen was then precipitated by salting out with $25 \%(\mathrm{w} / \mathrm{v}) \mathrm{NaCl}$ and centrifuged at 5,000 $\times \mathrm{g}$ for $30 \mathrm{~min}$. The resultant precipitate was dissolved in $0.5 \mathrm{M}$ acetic acid and centrifuged $(15,000 \times \mathrm{g}, 60 \mathrm{~min})$. The supernatant was dialyzed into distilled water for 5 days at $4^{\circ} \mathrm{C}$ and lyophilized. Calf and salmon skin type I collagens were purchased from Wako Pure Chemical Industries, Ltd., Japan and mackerel and carp collagen were extracted as mentioned above.

\subsection{Protein Recovery Rate and Collagen Yield}

Protein recovery rate was estimated by the Bradford method, and collagen yield (dry basis) of bluefin tuna abdominal skin was calculated by the following:

(Weight of final collagen sample, g)/(weight of bluefin tuna sample, g) $\times 100$

\subsection{Sodium Dodecyl Sulphate Polyacrylamide Gel Electrophoresis (SDS-PAGE) and Western Blotting}

SDS-PAGE was performed by the method of Laemmli [9] using the Tris-HCl/glycine buffer system with a 7.5\% resolving gel and 4\% stacking gel. The collagen sample was dissolved in sample buffer (0.5 M Tris-HCl, $\mathrm{pH}$ 6.8, containing 8\% SDS, 30\% glycerol, 0.2\% bromophenolblue) containing 5\% $\beta$-ME and then boiled for $5 \mathrm{~min}$. The samples were loaded and electrophoresed. For detection of bluefin tuna abdominal skin collagen, we prepared anti-fish collagen antibodies as follows. Salmon skin collagen type I ( $2 \mathrm{mg} / \mathrm{mL}$ ) was immunized into guinea pig five times. Then, the serum was drawn four times on days $0,24,31$, and 45 , and titers and reactivities were checked. For Western blotting, the sample was loaded onto SDS-PAGE gels, electrophoresed, and then transferred onto a PVDF membrane, followed by incubation for $1 \mathrm{hr}$ with primary antibody (1:150) at $25^{\circ} \mathrm{C}$. Blots were washed with PBST buffer $(3 \times 5 \mathrm{~min})$ and incubated for $1 \mathrm{hr}$ at $25^{\circ} \mathrm{C}$ with secondary antibody (anti-guinea pig IgG conjugated with peroxidase (1:1000)). The protein band on the membrane was detected on $\mathrm{X}$-ray film using the standard enhanced chemiluminescent (ECL) method (GE health care, USA).

\subsection{Preparation of Collagen Peptides}

Preparation of collagen peptides was performed by the method of Zhang et al. [10]. The extracted bluefin tuna abdominal skin collagen and salmon skin collagen were dissolved in $0.1 \mathrm{M}$ sodium phosphate buffer $(\mathrm{pH}$ 7.8) at a concentration of $6 \mathrm{mg} / \mathrm{mL}$. After adding 11,600 units/mg of trypsin (EC.3.4.21.4., Sigma Chemical Co.) to collagen solution $(0.07 \mu \mathrm{g} / \mathrm{mL})$, the reaction mixture was incubated at $37^{\circ} \mathrm{C}$ for $5 \mathrm{~min}$. To stop the reaction, the mixture was heated immediately at $100^{\circ} \mathrm{C}$ for $10 \mathrm{~min}$, followed by centrifugation at $10,000 \times \mathrm{g}$ for $10 \mathrm{~min}$ at $4^{\circ} \mathrm{C}$.

\subsection{Determination of Degree of Hydrolysis}

The degree of hydrolysis was determined by the 2,4,6,-trinitrobenzene sulfonic acid (TNBS) method $[11,12]$. One milliliter of $0.1 \%$ TNBS solution was added to $1 \mathrm{~mL}$ of sample solution $(0.15 \mathrm{mg} / \mathrm{mL})$ containing $1 \%$ sodium dodecyl sulfate (SDS) and $4 \% \mathrm{NaHCO}_{3}$ buffer ( $\mathrm{pH}$ 9.5). The resulting solution was rapidly mixed, reacted at $40^{\circ} \mathrm{C}$ for 2 hrs in a water bath, and finally stopped by the addition of $0.5 \mathrm{~mL}$ of $1 \mathrm{~N} \mathrm{HCl}$ and $10 \%$ SDS. The absorbance of the sample was read at 490 nm using a spectrophotometer against a blank control. The total number of amino groups was determined in a sample that was $100 \%$ hydrolyzed at $110^{\circ} \mathrm{C}$ for $24 \mathrm{hrs}$ in $6 \mathrm{~N} \mathrm{HCl}$ [13]. The absorbance of the sample was read at $490 \mathrm{~nm}$ against a blank, and the readings were converted to the number of free amino groups by comparison with a standard curve prepared using glycine.

\subsection{Cell Culture and MTT Assay}

HepG2 cells were grown in Dulbecco's-modified Eagle's medium (DMEM; Nissui, Tokyo, Japan) supplemented with 1\% Non-Essential Amino acids, 7.5\% Na$\mathrm{HCO}_{3}, 100$ units/mL of penicillin, $100 \mu \mathrm{g} / \mathrm{mL}$ of streptomycin, $200 \mathrm{mM}$ glutamine, and $100 \mathrm{mM}$ pyruvic acid in a $5 \% \mathrm{CO}_{2}$ incubator at $37^{\circ} \mathrm{C}$. HepG2 cells $\left(1.0 \times 10^{4}\right)$ 
were cultured in each well of a 96-well plate for 24 hrs at $37^{\circ} \mathrm{C}$ in a $\mathrm{CO}_{2}$ incubator. HeLa cells $\left(4.0 \times 10^{3}\right)$ were grown in medium (DMEM; Sigma, MO, USA) supplemented with 1\% Non-Essential Amino acids, 0.4\% Na$\mathrm{HCO}_{3}, 100$ units/mL of penicillin, $100 \mu \mathrm{g} / \mathrm{mL}$ of streptomycin, and $100 \mathrm{mM}$ pyruvic acid in a $5 \% \mathrm{CO}_{2}$ incubator at $37^{\circ} \mathrm{C}$. Sample solutions of various concentrations $(5,10$, 15 , and $20 \mu \mathrm{g} / 100 \mu \mathrm{L}$ of medium) were then added to the seeded HepG2 and HeLa cells, followed by 24 hrs of incubation at $37^{\circ} \mathrm{C}$ in a $\mathrm{CO}_{2}$ incubator. Relative cell growth was assayed by the MTT method, which is based on the protocol described by Mossmann. Briefly, cells were incubated for 4 hrs with $10 \mu \mathrm{L}$ of 3-(4,5-dimethylthiazol-2yl)-2,5-diphenyl-tetrazoliumbromide) (MTT) solution (5 $\mu \mathrm{g} / \mu \mathrm{L})$. After the detection of formazan under a microscope, the medium in the 96-well plates was removed by centrifugation $(500 \times \mathrm{g}, 15 \mathrm{~min})$. Isopropanol-0.04N HCl was added to the 96-well plates, followed by shaking for $15 \mathrm{~min}$. Then, $10 \mu \mathrm{L}$ of $3 \%$ SDS solution was added, after which the absorbance was recorded using a dual filter (595/655 nm).

\subsection{Caspase Activity and Cytotoxicity}

HepG2 $\left(1.0 \times 10^{4}\right)$ and HeLa cells $\left(4.0 \times 10^{3}\right)$ were seeded in 96-well plates and incubated for $24 \mathrm{hrs}$ at $37^{\circ} \mathrm{C}$ in a $\mathrm{CO}_{2}$ incubator. After incubation, samples $(20 \mu \mathrm{g} / 100$ $\mu \mathrm{l}$ of medium) were added, and the plate was incubated for 24 hrs at $37^{\circ} \mathrm{C}$ in a $\mathrm{CO}_{2}$ incubator. Caspase activity and cytotoxicity were measured using a Caspase-Glo assay kit (Promega Co. USA) and CytoTox96 non-radioactive cytotoxicity assay kit (Promega Co. USA). Namely, cells in medium $(100 \mu \mathrm{L})$ were collected using trypsin inhibitor and spinned down for 2 min. The medium was then exchanged with $100 \mu \mathrm{L}$ of new medium, followed by mixing of the samples. For measurement of caspase activities, $20 \mu \mathrm{L}$ of sample medium was added to the assay plate along with $20 \mu \mathrm{L}$ of substrate mixed with buffer. The assay plate was then reacted for $30 \mathrm{~min}$ at room temperature, and the luminescence of the plate was measured. For the cytotoxicity assay, $30 \mu \mathrm{L}$ of sample medium was added to the assay plate, after which 30 $\mu \mathrm{L}$ of substrate mixed with buffer was added, mixed, and reacted for $30 \mathrm{~min}$ at room temperature while excluding light using aluminum foil. Then, $30 \mu \mathrm{L}$ of $1 \mathrm{M}$ acetic acid was added to the plate, and the absorbance was measured at $490 \mathrm{~nm}$.

\subsection{Statistical Analysis}

Analysis of variance (ANOVA) was performed, and differences among the samples were determined by Duncan's Multiple Range Test using the Statistical Analy- sis System. $P$ values $(p<0.05)$ were considered significant.

\section{RESULTS AND DISCUSSION}

\subsection{Electrophoresis and Western Blotting}

The collagen samples from bluefin tuna abdominal skin and reagent grade salmon were analyzed by $7.5 \%$ SDS-PAGE (Figure 1). The separation pattern shows that bluefin tuna abdominal skin and salmon skin collagen were composed of two $\alpha$ chains ( $\alpha 1$ and $\alpha 2)$ and one $\beta$ chain. The purity of the collagen extracted from bluefin tuna abdominal skin was $83.7 \%$. The density of the $\alpha 1$ chain was higher than that of the $\alpha 2$ chain for both bluefin tuna abdominal skin collagen and salmon skin collagen. This result is similar to previous reports on other fish species and is typical of type I collagen $[14,15]$. The estimated molecular weights for the $\alpha 1$ and $\alpha 2$ chains compared to a standard were approximately 120 and $112 \mathrm{kDa}$, respectively [16]. From the results, the $\alpha 1, \alpha 2$, and $\beta$ chains of bluefin tuna abdominal skin collagen were lower purity than those of salmon skin collagen. The $\beta$ chain is a dimer with a molecular weight of approximately $205 \mathrm{kDa}$. The SDS-PAGE patterns of the $\beta$ chain were similar regardless of fish species. The topmost band was likely due to agglomeration of protein particles by proteolysis during electrophoresis. The collagen extracted from bluefin tuna abdominal skin showed a clearer SDS-PAGE pattern at the low molecular weight region compared to that of salmon. The prepared antisera against salmon skin collagen were reacted with bluefin tuna abdominal skin collagen and salmon skin collagen. The reactivity of salmon collagen was high while the reactivity of bluefin tuna abdominal skin collagen was not relatively high. This result seems to suggest that bluefin tuna abdominal skin collagen and salmon skin collagen differed in sequence.

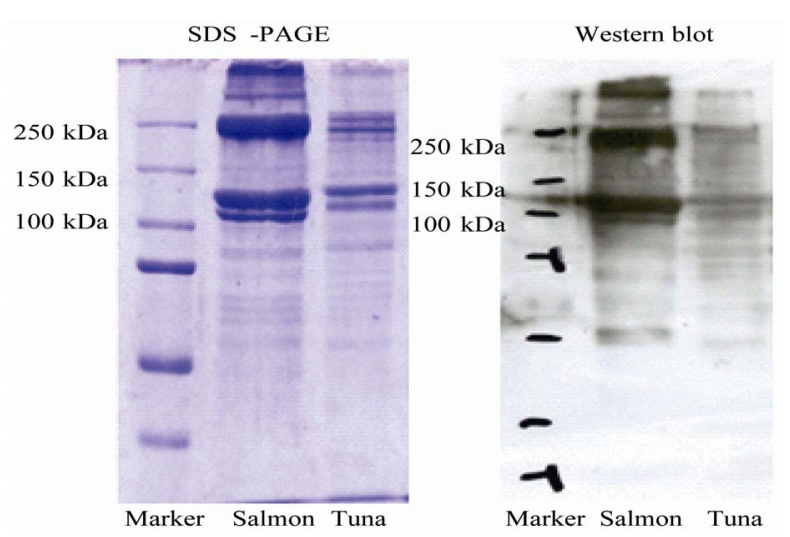

Figure 1. SDS-PAGE of fish skin collagen and Western blot analysis by using antisera. SAC: Salmon skin collagen; TUC: Bluefin tuna abdominal skin collagen. 


\subsection{Degree of Hydrolysis}

The peptides of bluefin tuna abdominal skin collagen and salmon skin collagen were prepared by trypsin digestion. The degree of hydrolysis of salmon skin collagen peptides was 53.1\%, whereas the degree of hydrolysis of bluefin tuna abdominal skin collagen peptides was $96.2 \%$. Therefore, the degree of hydrolysis of prepared salmon skin collagen peptides was lower than that of collagen peptides from bluefin tuna abdominal skin by $43 \%$. The residue content of collagen (MW 300,000) upon hydrolysis into only glycine residues produced $2.25 \times$ $10^{10} \mathrm{~mol}\left(1 \mathrm{mg}\right.$ of glycine $\left.=1.33 \times 10^{-5} \mathrm{~mol}\right)$. Therefore, we assumed that the residue content of hydrolyzed (96.2\%) bluefin tuna abdominal skin collagen was 2.16 $\times 10^{10}$ mol while that of hydrolyzed (53.1\%) salmon skin collagen was $1.20 \times 10^{10} \mathrm{~mol}$. These results are perhaps due to differences in amino acid and imino acid content between bluefin abdominal skin collagen and salmon skin collagen [15]. The high imino acid content of collagen increased the thermal stability of collagen. Denaturation of collagen occurs at above $25^{\circ} \mathrm{C}$ during enzyme digestion, and any lower temperature reduces enzyme activity under the same conditions. Therefore, salmon skin collagen contained higher imino acid content than that of bluefin tuna abdominal skin collagen. Furthermore, amino acid content had some effects on the thermal stability of collagen. According to another report, differences in amino acid composition affected the denaturation point [17]. For instance, collagen sample with high leucine and lysine content had a higher denaturation point.

\subsection{Effect of Collagen and Collagen Peptides on Growth Inhibition of Cells}

Effects of collagen and collagen peptides on growth inhibitor of cells are shown in Figure 2. We investigated the adding timing effect of the collagen and collagen peptides samples on HepG2 and HeLa cells. Samples at the same concentration were added to HepG2 and HeLa cells seeded in 96-well plates. HepG2 and HeLa cell growth increased with the concentrations of salmon collagen, salmon collagen peptides, and bluefin tuna abdominal skin collagen peptides. However, cell growth decreased upon the addition of bluefin tuna abdominal skin collagen. Salmon skin collagen and salmon collagen peptides induced increased HepG2 cell growth by 35\% while bluefin tuna abdominal skin collagen peptides increased relative HepG2 cell growth by 30\%. HeLa cells also experienced similar increases in relative growth. Salmon collagen and salmon collagen peptides increased relative HeLa cell growth by over $50 \%$. This result was similar with other reported reports, which showed that collagen is able to stimulate cell proliferation and
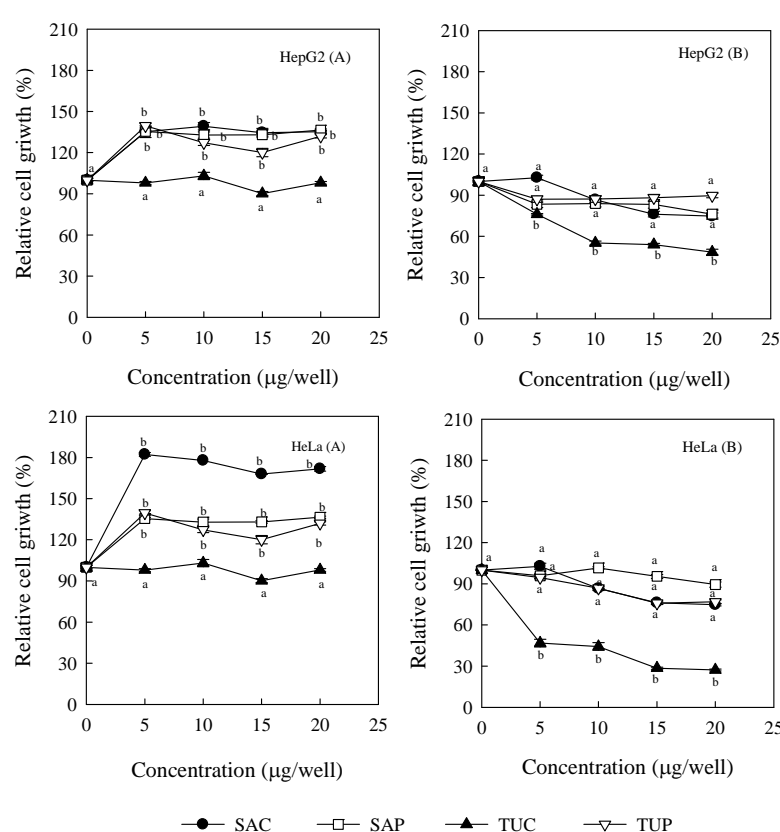

Figure 2. Effect of salmon skin collagen, bluefin tuna abdominal skin collagen, and their peptides on HepG2 and HeLa cell growth by MTT assay. The seeded cells were not incubated, and the samples were added to cells seeded in a 96-well plate. Then, the cells were incubated for $24 \mathrm{hrs}$ in a $37^{\circ} \mathrm{C}$ incubator (HepG2 (A) and HeLa (A)). The seeded cells were incubated for $24 \mathrm{hrs}$ at $37^{\circ} \mathrm{C}$ after which the samples were added. After addition of the collagen samples, the cells were incubated again for $24 \mathrm{hrs}$ in a $37^{\circ} \mathrm{C}$ incubator (HepG2 (B) and HeLa (B)). Control: No addition sample; SAC: Salmon skin collagen; SAP: Salmon skin collagen peptides; TUC: Bluefin tuna abdominal skin collagen; TUP: Bluefin tuna abdominal skin collagen peptides. ${ }^{*} p<0.05$ compared with control.

adhesion when added during cell seeding. It may be that the availability of collagen increases the stability of the cytoskeleton as well as activation of signal transduction. Moreover, the effect differs (increase or reduction of relative cell growth) according to fish type and the molecular weight of collagen [18]. Bluefin tuna collagen reduced cell growth when added to HepG2 and HeLa cells seeded in 96-well plates (50\% reduction of HepG2 cell growth and 38\% reduction of HeLa cell growth). More specifically, relative cell growth decreased with the concentration of bluefin tuna abdominal skin collagen with dependence on cell type. The reduction of cell growth by collagen was affected by cell type. The both prepared collagen peptides showed not relative cell growth reduction, significantly. We also compared the effects of other fish collagens on cells (Figure 3). Bluefin tuna abdominal skin collagen had a relatively large effect on cell growth. These results show demonstrate the effects of fish type, fish skin collagen, fish skin collagen peptides, and the duration of collagen and collagen peptide treatment. Particularly, addition of bluefin tuna 


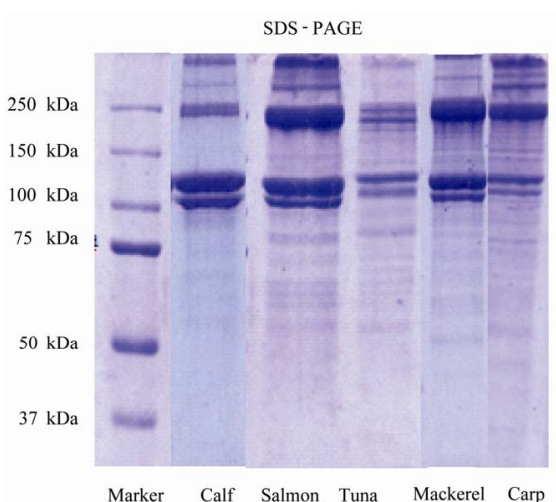

(a)
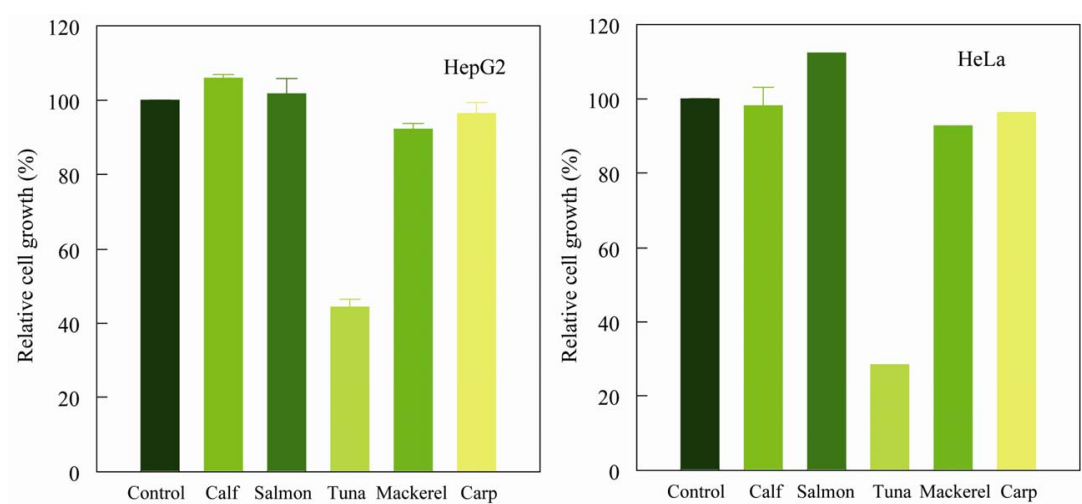

(b)

Figure 3. Effects of salmon skin collagen, bluefin tuna abdominal skin collagen, trout skin collagen, and carp skin collagen (20 $\mu \mathrm{g} /$ well) on HepG2 and HeLa cell growth by MTT assay. The seeded cells were incubated for 24 hrs at $37^{\circ} \mathrm{C}$ after which the samples were added. After addition of the collagen samples, the cells were incubated again for 24 hrs in a $37^{\circ} \mathrm{C}$ incubator (A). SDS-PAGE of trout skin collagen and carp skin collagen.

abdominal skin collagen during cell attachment resulted in decreased relative cell growth. This result suggests the possibility that collagen may have a negative effect on cancer cell growth and also that the duration of collagen treatment is very important. It was reported that shark cartilage modulates the immune response [19]. Specifically, shark cartilage inhibits the proliferation and migration of endothelial cells through the fibrin matrix, which implies the modulation of adhesion molecules on the surfaces of endothelial cells. Namely, when collagen was added to attach cells, cell-cell adhesion was interrupted. However, there was a positive effect observed when collagen was added during cell seeding. These results suggest the possibility that other fish collagens have effects on cells. For example, collagen is a sort of optically-active protein. However, the hydrolysis of collagen induces collapse of the triple helix conformation [20]. This implies that the different structures of collagen and collagen peptides influenced adhesion molecules on the surfaces of HepG2 and Hela cells. Furthermore, the shape and density of the collagen strands had an effect on cell growth. According to our data (Table 1), the in hibition of relative cell growth was most likely not due to cell apoptosis or necrosis. However, understanding the reduction in cell growth is difficult since the related mechanisms are very complex. Therefore, further investigation of the purified $\alpha$ and $\beta$ bands of collagen in the cells as well as the mechanisms of apoptosis, necrosis, and growth inhibition is needed.

\section{CONCLUSION}

In this paper, we describe the preparation and effects of collagen and collagen peptides from bluefin tuna abdominal skin on HepG2 and HeLa cells. The main protein band of bluefin tuna abdominal skin collagen and reagent grade salmon skin collagen consisted of two $\alpha$ chains and one $\beta$ chain. The degree of hydrolysis (DH) of peptides from bluefin tuna abdominal skin collagen was higher than that of salmon skin collagen by $43.1 \%$. Bluefin tuna abdominal skin collagen had a large inhibitory effect on HepG2 and HeLa cell growth. The duration of collagen treatment was also important. These results suggest a role for collagen from bluefin tuna abdominal skin waste as a functional component in the treatment of attached human cancer cells.

Table 1. Caspase activity and cytotoxicity.

\begin{tabular}{lccc}
\hline & Caspase 3/7 & Caspase 9 & Cytotoxicity \\
\hline HepG2 cell & & & \\
Control & $100.0 \pm 2.6^{\mathrm{a} 1}$ & $100.0 \pm 1.2^{\mathrm{a}}$ & $100.2 \pm 0.9^{\mathrm{a}}$ \\
Calf & $94.7 \pm 3.7^{\mathrm{a}}$ & $94.1 \pm 7.1^{\mathrm{a}}$ & $98.6 \pm 4.8^{\mathrm{a}}$ \\
Salmon collagen & $99.6 \pm 3.9^{\mathrm{a}}$ & $103.6 \pm 5.6^{\mathrm{a}}$ & $98.1 \pm 1.9^{\mathrm{a}}$ \\
Tuna collagen & $96.8 \pm 5.7^{\mathrm{a}}$ & $97.7 \pm 6.3^{\mathrm{a}}$ & $98.3 \pm 2.0^{\mathrm{a}}$ \\
Mackerel collagen & $91.5 \pm 5.0^{\mathrm{a}}$ & $95.7 \pm 6.0^{\mathrm{a}}$ & $100.2 \pm 1.1^{\mathrm{a}}$ \\
Carp collagen & $97.3 \pm 7.5^{\mathrm{a}}$ & $101.6 \pm 2.2^{\mathrm{a}}$ & $100.9 \pm 0.9^{\mathrm{a}}$ \\
HeLa cell & & & \\
Control & $100.2 \pm 1.2^{\mathrm{a}}$ & $100.2 \pm 3.0^{\mathrm{a}}$ & $100.0 \pm 3.0^{\mathrm{a}}$ \\
Calf & $99.7 \pm 5.6^{\mathrm{a}}$ & $92.1 \pm 8.0^{\mathrm{a}}$ & $96.6 \pm 2.5^{\mathrm{a}}$ \\
Salmon collagen & $101.0 \pm 2.1^{\mathrm{a}}$ & $94.6 \pm 2.1^{\mathrm{a}}$ & $97.2 \pm 2.8^{\mathrm{a}}$ \\
Tuna collagen & $98.5 \pm 5.9^{\mathrm{a}}$ & $103.2 \pm 3.4^{\mathrm{a}}$ & $96.2 \pm 5.1^{\mathrm{a}}$ \\
Mackerel collagen & $100.9 \pm 3.8^{\mathrm{a}}$ & $100.9 \pm 4.4^{\mathrm{a}}$ & $101.4 \pm 3.8^{\mathrm{a}}$ \\
Carp collagen & $98.10 \pm 3.2^{\mathrm{a}}$ & $100.6 \pm 1.7^{\mathrm{a}}$ & $102.3 \pm 0.4^{\mathrm{a}}$ \\
\hline
\end{tabular}

${ }^{1}$ Superscripts in an each low of HepG2 and HeLa cell indicated significantly different difference at $\mathrm{p}<0.05$ by Ducan's multiple comparisons. 


\section{ACKNOWLEDGEMENTS}

This work was supported by GCOE project Grant of Kinki University 2009.

\section{REFERENCES}

[1] Knekt, P., Jarvinen, R., Seppanen, R., Heliovaara, M., Teppo, L., Pukkala, E. and Aromaa, A. (1997) Dietary flavoniods and the risk of lung cancer other malignant neoplasmas. American Journal of Epidemology, 146, 223-230.

[2] Jongjareonrak, A., Benjakul, S., Visessanguan, W., Nagai, T. and Tanaka, M. (2005) Isolation and charaterisation of acid and pepsin-solubilised collagens from skin of Brownstripe red snapper (Lutjanus vitta). Food Chemistry, 93, 475-484. doi:10.1016/j.foodchem.2004.10.026

[3] Mizuta, S., Fujisawa, S., Nishimoto, M. and Yoshinaka, R. (2005) Biochemical and immunochemical detection of type I and V collagens in tiger puffer Takifugu ruripes. Food Chemistry, 89, 373-377. doi:10.1016/j.foodchem.2004.02.043

[4] Nagai, T. and Suzuki, N. (2002) Preparation and partial characterization of collagen from paper nautilus (Argonauta argo, Linnaeus) outer skin. Food Chemistry, 76, 149-153. doi:10.1016/S0308-8146(01)00255-2

[5] Hwang, J.H., Mizuta, S., Yokoyama, Y. and Yoshinaka, R. (2005) Purification and characterization of molecular species of collagen in the skin of skate (Raja Kenojei). Food Chemistry, 100, 921-925. doi:10.1016/j.foodchem.2005.10.046

[6] Tsuruoka, N., Yamato, R., Sakai, Y., Yoshitake, Y. and Yonekura, H. (2007) Promotion by collagen tripeptide of type I collagen gene expression in human osteoblastic cells and fracture healing of rat femur. Bioscience Biotechnology Biochemistry, 71, 2680-2687. doi:10.1271/bbb.70287

[7] Gozalea, R.P., Leyva, A. and Moraes, O. (2001) Shark cartilage as source of antiangiogenic compound: from basic to clinic research. Biological \& Pharmaceutical Bulletin, 24, 1097-1101. doi:10.1248/bpb.24.1097

[8] Omenn, G.S., Goodmay, G.E., Thornquist, M.D., Balmes, J., Cullen, M,R., Glass, A., Keogh, J.P., Meysken, F.L., Valanis, B., Williams, J., Barnhart, S. and Hammar, S. (1996) Effects of a combination of beta carotene and vitamin A on lung cancer and cardiovascular disease. The New England Journal of Medicine, 334, 1150-1155. doi:10.1056/NEJM199605023341802

[9] Laemmli, U.K. (1970) Cleavage of structural proteins during assembly of head bacterriophage T4. Nature, 277, 680-685. doi:10.1038/227680a0

[10] Zhang, Y., Liu W., Li, G., Shi, B., Miao, Y. and Wu, X., Physicochemical properties of collagen, gelatin and collagen hydroysate derived from bovine limed split waste.
(2005) Food Chemistry, 103, 906-912. doi:10.1016/j.foodchem.2006.09.053

[11] Achouri, A., Zhang, W. and Shiying, X. (1998) Isolation and partial characterization of pepsin-soluble collagen from the skin of grass carp (Ctenopharyngodon idella). Food Research International, 31, 617-623. doi:10.1016/S0963-9969(98)00104-5

[12] Adler-Nissen, J. (1979) Enzymatic hydrolysis of soy protein isolate and effect of succinylation on the functional properties of resulting protein hydrolysates. Journal of Agriculture Food Chemistry, 27, 1256-1262. doi:10.1021/jf60226a042

[13] Shoji, Y., Isemura, M., Muto, H. and Isemura, S. (2000) Isolation of 41-kDa protein with cell adhesion activity for animal tumor cells from the mushroom Hypsizigus marmoreus by affinity chromatography with type IV collagen immobilized on agaros. Bioscience Biotechnology Biochemistry, 64, 775-780. doi:10.1271/bbb.64.775

[14] Muyonga, J.H., Cole, C.G.B. and Doudu, K.G. (2004) Charaterisation of acid soluble collagen from skins of young and adult nile perch (Lates niloticus). Food Chemistry, 85, 81-89. doi:10.1016/j.foodchem.2003.06.006

[15] Yata, M., Yoshida, C., Fujisawa, S. and Yoshinaka, Y., (2001) Identification and characterization of molecular species of collagen in fish skin. Journal of Food Science, 66, 247-251. doi:10.1111/j.1365-2621.2001.tb11325.x

[16] Nalinanon, S., Benjakul, S., Visessanguan, W. and Kishimura, H. (2007) Use of pepsine for collagen extraction from the skin of bigeye smapper (Priaca nthus tayenus). Food Chemistry, 104, 591-601. doi:10.1016/j.foodchem.2006.12.035

[17] Nomura, Y., Sakai, H. and Shirai, K. (1996) Preparation and some properties of type I collagen from fish scales. Bioscience Biotechnology Biochemistry, 60, 2092-2094. doi:10.1271/bbb.60.2092

[18] Nagai N., Mori K., Satoh Y., Takahashi N., Yunoki S., Tajima K. and Munekata M., (2007) In vitro growth and differentiated activities of human periodontal ligment fibroblasts cultured salmon collagen gel. Journal of Biomedical Materials Research Part A, 395-402. doi:10.1002/jbm.a.31110

[19] Close, M.J., Howlett, A.R., Roskelley, C.D., Desprez, P.Y., Bailey, N., Rowning, B., Teng, C.T., Stampfer, M.R. and Yaswen, P. (1997) Lactoferrin expression in mammary epithelial cell is mediated by changes in cell shape and action cytoskeleton. Journal of Cell Science, 110, 2861-2871.

[20] Hassan, Z.M., Feyzi, R., Sheikhian, A., Bargahi, A., Mostafaie, A., Mansouri, K., Shahrokhi, S., Ghazanfari, T. and Shahabi, S. (2005) Molecular weight fraction of shark cartilage can modulated immine responses and abolish angiogenesis. International Immunophamacology, 5, 961-970. doi:10.1016/j.intimp.2005.01.006 